\title{
АНТИКОРРУПЦИОННОЕ ОБРАЗОВАНИЕ В ОРГАНАХ ВНУТРЕННИХ ДЕЛ РОССИЙСКОЙ ФЕДЕРАЦИИ (НА ПРИМЕРЕ УРАЛЬСКОГО ЮРИДИЧЕСКОГО ИНСТИТУТА Мвд РОсСиИ)
}

\author{
Чашников В.A.
}

\begin{abstract}
Аннотация: В статье рассматривается антикоррупционое образование как эффективная мера профилактики коррупции в органах внутренних дел Российской Федерации. В статье представлен опыт преподавания дисииплины «Предупреждение коррупции в органах внутренних дел и формирование антикоррупционного поведения сотрудников и работников органов внутренних дел» на примере Уральского юридического института Министерства внутренних дел Российской Федерации в соответствии с квалификационными требованиями, предъявляемыми к выпускникам по специальностям 031001.65 Правоохранительная деятельность, 030901.65 Правовое обеспечение начиональной безопасности. Метод, методология исследования. В процессе исследования применялись общефилософские методы (диалектика, системный метод, анализ, синтез, аналогия, дедукиия, наблюдение, моделирование), правовые методы (формально-логический), а также методы, используемые в конкретно-социологических исследованиях (статистические, экспертные оченки и др.). Новизна исследования, выводы. Автор считает, что одной из важнейших мер профилактики коррупции в органах внутренних дел является антикоррупиионное образование. Автор делает вывод о том, что иель антикоррупционного образования заключается в получении, обновлении знаний, совершенствовании навыков сотрудников органов внутренних дел в сфере противодействия коррупции, формировании антикоррупиионного стандарта поведения. Кроме того, антикоррупиионное образование сотрудников органов внутренних дел должно охватывать общие вопросы государственной антикоррупционной политики, опыт зарубежных государств по профилактике и противодействию коррупции, соответствующее уголовное законодательство, так и специальные мероприятия и механизмы противодействия коррупции, реализуемые в органах внутренних дел (представление сведений о доходах, расходах, имуществе и обязательствах имущественного характера, организаиия уведомления сотрудниками органов внутренних дел представителя нанимателя о фактах обращения в иелях склонения к совершению коррупиионных правонарушений, проведение антикоррупционных проверок и другие).
\end{abstract}

Ключевые слова: Антикоррупчионное образование, органы внутренних дел, принщип, служба, коррупция, поведение, мораль, нравственность, стандарт, мероприятия. 
Общеизвестно, что основными принципами государственной службы являются служение обществу и государству, а свою деятельность сотрудник полиции должен строить на уважении к личности, строгом соблюдении закона и бескорыстии. Последний принцип лежит в основе стандартов антикоррупционного поведения[1].

Коррупционно опасным поведением принято считать такое действие или бездействие должностного лица, которое в ситуации конфликта интересов создаёт предпосылки и условия для получения им корыстной выгоды и преимуществ как для себя, так и для иных лиц, организаций, учреждений, чьи интересы прямо или косвенно отстаиваются лицом, незаконно использующим своё служебное положение. Коррупционно опасной будет являться любая ситуация в служебной деятельности, которая создает возможность нарушения норм, ограничений и запретов, установленных законодательством Российской Федерации для государственного служащего.

Такие ситуации пагубно сказываются на авторитете власти, подрывают доверие к ней со стороны населения. В целях создания действительно работоспособной структуры власти необходимо у каждого сотрудника полиции, каждого государственного и муниципального служащего сформировать навыки антикоррупционного поведения, что в первую очередь предусматривает сознательное возложение им на себя моральных обязательств, ограничений и запретов.

Нравственные обязательства не позволяют сотруднику полиции заниматься предпринимательской деятельностью, выстраивать отношения личной заинтересованности с лицами, занимающимися предпринимательской деятельностью, составлять им протекцию, использовать служебное положение для организации своей карьеры в бизнесе, управлении политическими партиями и организациями, давать личные обещания, расходящиеся с должностными обязанностями, принимать какие-либо почести, вознаграждения, поощрения, связанные с определенными условиями, не предусмотренными официальным регламентом.

Морально недопустимым для сотрудника полиции считается получение подарков (услуг, приглашений и любой другой выгоды) в благодарность за совершение каких-либо официальных действий. При этом ему запрещено давать какие-либо основания или поводы для попытки вручения подарка или другого вида вознаграждения.
Формирование таких стандартов поведения начинается, прежде всего, с предъявления требований к самому себе, воспитания необходимых черт характера. Нравственная чистоплотность, неподкупность сотрудника полиции, его преданность интересам службы, верность служебному долгу составляют основу профессиональноэтического стандарта антикоррупционного поведения. И те свойства человеческого характера, которые традиционно рассматривались как высокоморальные устои личности, являются неотъемлемой стороной служебной деятельности полицейского, показателем совершенства его профессионального мастерства, уровня его нравственного и культурного развития[2].

В Российской Федерации формируется многоуровневая система антикоррупционного образования, в которой принимают с разной степенью активности участие государственные органы и учреждения, субъекты образовательной деятельности и институты гражданского общества[3]. Особенно важным является антикоррупционное образование сотрудников правоохранительных органов, которые, с одной стороны, находятся на переднем крае борьбы с соответствующими правонарушениями, a, с другой, сами в значительной степени подвержены рискам коррупционного разложения. Наработанный специалистами отдельных образовательных организаций высшего профессионального образования, расположенных в субъектах Российской Федерации, на наш взгляд, может быть использован и в этой сфере[4].

Антикоррупционное образование сотрудников органов внутренних дел является одним из наиболее эффективных и перспективных направлений противодействия коррупции. Об этом постоянно упоминают большинство специалистов в области противодействия коррупции, объясняя это тем, что для антикоррупционной деятельности необходимы подготовленные (хорошо обученные) кадровые ресурсы[5].

На формирование навыков активной антикоррупционной деятельности направлен и недавно принятый Министерством образования и науки России федеральный образовательный стандарт высшего профессионального образования по направлению подготовки «Юриспруденция»[6]. Стоит отметить, что ведение специальных курсов, дисциплин по изучению антикоррупционного законодательства и способах борьбы с коррупцией стало обыденной практикой [7]. 
В Уральском юридическом институте МВД России преподается дисциплина «Предупреждение коррупции в органах внутренних дел и формирование антикоррупционного поведения сотрудников и работников органов внутренних дел» в соответствии с квалификационными требованиями, предъявляемыми к выпускникам по специальностям 031001.65 Правоохранительная деятельность, 030901.65 Правовое обеспечение национальной безопасности. Она имеет комплексный управленческий и правовой характер. Цель изучения дисциплины - подготовить к формированию установки на соблюдение стандартов антикоррупционного поведения у сотрудников органов внутренних дел.

Задачи дисциплины состоят в получении и закрепление знаний о проводимой в Российской Федерации антикоррупционной политике; выработке навыков и умений антикоррупционного поведения у сотрудников органов внутренних дел в процессе осуществления правоохранительной деятельности; соблюдении антикоррупционного стандарта поведения.

Процесс изучения дисциплины направлен на формирование общекультурных и профессиональных компетенции, среди которых способность осуществлять профессиональную деятельность на основе развитого правосознания, правового мышления и правовой культуры; способность осуществлять профилактику, предупреждение преступлений и иных правонарушений на основе использования закономерностей преступности, преступного поведения и методов их предупреждения, выявлять и устранять причины и условия, способствующие совершению правонарушений; способность выявлять и содействовать пресечению коррупционных проявлений в служебном коллективе и другие.

В результате изучения дисциплины обучаемые должны знать о сущности коррупции как негативного социально-правового явления общественной жизни и проводимой в Российской Федерации антикоррупционной политике, основных направлениях противодействия коррупции в органах внутренних дел и формирования антикоррупционного поведения сотрудников органов внутренних дел; уметь противодействовать коррупционным проявлениям, организовывать, планировать и осуществлять антикоррупционные мероприятия в служебном коллективе; владеть навыками антикоррупционного поведения в процессе осуществления оперативно-служебной деятельности.
В программу дисциплины включены вопросы, раскрывающие поставленные задачи: понятие и содержание коррупции как негативного социально-правового явления; основные цели и задачи государственной политики в сфере противодействия коррупции; приоритетные направления деятельности органов внутренних дел в сфере противодействия коррупции; система противодействия коррупции и формирования антикоррупционного поведения сотрудников и служащих ОВД; организационно-правовые основания и пути формирования антикоррупционного поведения сотрудников и служащих ОВД; особенности воспитательной работы по обеспечению антикоррупционного поведения сотрудников и служащих ОВД; условия, методы и приемы противодействия попыткам криминальных и асоциальных лиц стимулировать коррумпированные действия сотрудников и служащих ОВД[8].

Материал дисциплины изучается на лекциях, семинарах и практических занятиях, а также в процессе самостоятельной работы обучаемых.

В ходе лекций обучающиеся получают теоретические знания по вопросам, обозначенным в тематическом плане. На семинарских занятиях слушатели закрепляют полученные знания путем устных или письменных ответов на поставленные вопросы. В ходе практических занятий обучаемые решают задачи, опрашиваются теоретически, исследуют уголовные дела, делают небольшие доклады по отдельным вопросам темы.

Для обеспечения образовательного процесса при реализации дисциплина «Предупреждение коррупции в органах внутренних дел и формирование антикоррупционного поведения сотрудников и работников органов внутренних дел» в соответствии с квалификационными требованиями, предъявляемыми к выпускникам по специальностям 031001.65 Правоохранительная деятельность, 030901.65 Правовое обеспечение национальной безопасности созданы учебнометодические комплексы, которые включают в себя: рабочие программы учебных дисциплин, тексты лекций, методические разработки для проведения семинарских и практических занятий, методические материалы для организации активных форм обучения по практическим и семинарским занятиям (деловые игры, тренинги, учения), методические рекомендации для организации самостоятельной работы обучающихся, тематику (задания) письменных работ и мето- 
дические рекомендации по их написанию, фонд оценочных материалов, разработанные на кафедре учебники (в том числе электронные), курсы лекций, учебные, учебно-методические пособия, альбомы схем, сборники статей и прочее.

В Уральском юридическом институте МВД России также проводится работа по обеспечению антикоррупционного поведения среди сотрудников института. В рамках правовой подготовки проводятся занятия по разъяснению антикоррупционного законодательства с участием специалистов и практических работников органов внутренних дел.

Для получения информации и оперативного реагирования на коррупционные и иные правонарушения в институте осуществляются следующие организационно-практические мероприятия:

- размещен специальный почтовый ящик для обращений, заявлений и жалоб граждан и организаций, в том числе для получения информации о возможных фактах коррупционных правонарушений среди личного состава;

- организована работа «телефона доверия» в круглосуточном режиме;

- осуществляется работа по сбору и мониторингу информации о возможных фактах коррупционных правонарушений, размещенной в сети Интернет, СМИ, и из иных источников;

На плановой основе реализуются совместные мероприятия института с ГУ МВД России по
Свердловской области и отдела по надзору за исполнением законодательства о противодействии коррупции прокуратуры Свердловской области.

Таким образом, в Министерстве внутренних дел Российской Федерации большое внимание уделяется статусу сотрудника органов внутренних дел, что определяется современными потребностями борьбы с коррупционными проявлениями в органах внутренних дел. В таком случае необходимо ввести в статус сотрудника органа внутренних дел антикоррупционные механизмы предупреждающего, реагирующего, наказывающего характера.

Выработка единого образца поведения антикоррупционного содержания для сотрудника органа внутренних дел позволит предупредить совершение коррупционных проступков, снизить вероятность их совершения, оказать информационное содействие сотруднику органа внутренних дел при использовании алгоритма поведения в случае установления факта коррупционного действия в отношении сотрудника органа внутренних дел. Соответствующее теоретическое осмысление уже состоялось, что нашло отражение в законодательстве. Однако изменяющиеся формы коррупционных проявлений вызывают потребность регулярного научного и законодательного сопровождения содержания стандарта антикоррупционного поведения сотрудника органа внутренних дел.

\section{Библиография:}

1. Ахметова Н.А., Гузенко В.Н. Основы антикоррупционного образования в современном учебном процессе / Н.А. Ахметова, В.Н. Гузенко // Известия Волгоградского государственного технического университета. - 2013. - Т. 10. - № 13 (116). - С. 16-18.

2. Борзенко Ю.А. Антикоррупционное образование курсантов / Ю.А. Борзенко // Вестник Кузбасского института. - 2013. - № 4 (17). - С. 127-130.

3. Губарева Т.И. Воспитательная функция в юридическом образовании в свете проводимой антикоррупционной политики / Т.И. Губарева // Юридическое образование и наука. - 2013. - № 3. - С. 12-14.

4. Емельянова Н.И. Антикоррупционное образование в российских учебных заведениях / Н.И. Емельянова, М.Л. Подкатилина // Юридическое образование и наука. - 2014. - № 2. - С. 15-18.

5. Кабанов П. А. Антикоррупционное образование в органах внутренних дел Российской Федерации: современное состояние и перспективы развития / П. А. Кабанов // Следователь. -2011. - № 2. - С. 36-40.

6. Костенников М.В. К вопросу о противодействии коррупции в полиции / М.В. Костенников // Административное и муниципальное право. - 2013. - № 1. - С. 48-50.

7. Николаев С.М. Специальное антикоррупционное образование в России: системный подход / С.М. Николаев // Инновации в образовании. - 2014. - № 6. - С. 138-146.

8. Приказ Минобрнауки России от 5 декабря 2014 № 1538 «Об утверждении федерального государственного образовательного стандарта высшего образования по направлению подготовки 40.06 .01 Юриспруденция (уровень подготовки кадров высшей квалификации)» // Российская газета. - 2015. - № 21. 


\section{References (transliterated):}

1. Akhmetova N.A., Guzenko V.N. Osnovy antikorruptsionnogo obrazovaniya v sovremennom uchebnom protsesse / N.A. Akhmetova, V.N. Guzenko // Izvestiya Volgogradskogo gosudarstvennogo tekhnicheskogo universiteta. - 2013. - T. 10. - № 13 (116). - S. 16-18.

2. Borzenko Yu.A. Antikorruptsionnoe obrazovanie kursantov / Yu.A. Borzenko // Vestnik Kuzbasskogo instituta. - 2013. - № 4 (17). - S. 127-130.

3. Gubareva T.I. Vospitatel'naya funktsiya v yuridicheskom obrazovanii v svete provodimoi antikorruptsionnoi politiki / T.I. Gubareva // Yuridicheskoe obrazovanie i nauka. - 2013. - № 3. - S. 12-14.

4. Emel'yanova N.I. Antikorruptsionnoe obrazovanie v rossiiskikh uchebnykh zavedeniyakh / N.I. Emel'yanova, M.L. Podkatilina // Yuridicheskoe obrazovanie i nauka. - 2014. - № 2. - S. 15-18.

5. Kabanov P. A. Antikorruptsionnoe obrazovanie v organakh vnutrennikh del Rossiiskoi Federatsii: sovremennoe sostoyanie i perspektivy razvitiya / P. A. Kabanov // Sledovatel'. - 2011. - № 2. - S. 36-40.

6. Kostennikov M.V. K voprosu o protivodeistvii korruptsii v politsii / M.V. Kostennikov // Administrativnoe i munitsipal'noe pravo. - 2013. - № 1. - S. 48-50.

7. Nikolaev S.M. Spetsial'noe antikorruptsionnoe obrazovanie v Rossii: sistemnyi podkhod / S.M. Nikolaev // Innovatsii v obrazovanii. - 2014. - № 6. - S. 138-146.

8. Prikaz Minobrnauki Rossii ot 5 dekabrya 2014 № 1538 «Ob utverzhdenii federal'nogo gosudarstvennogo obrazovatel'nogo standarta vysshego obrazovaniya po napravleniyu podgotovki 40.06.01 Yurisprudentsiya (uroven’ podgotovki kadrov vysshei kvalifikatsii)» // Rossiiskaya gazeta. - 2015. - № 21. 